\title{
"What a Soul in Those Soaring Shapes": Transcaucasia in XIX century British Writing
}

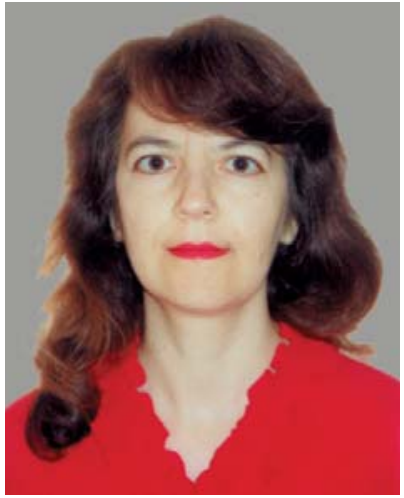

Stella Nuralova

A or centuries the Caucasus, Ararat and Armenia have exercised a powerful hold over the imagination of many British authors.

The title of the paper may seem somewhat large and ambitious for now, after numerous books, articles and symposia have explored and described many aspects of the problem. My topic has only a limited focus. A new field is not to be introduced, but the potentials of the proposed research are, nevertheless, limitless. Each decade pronounces its own judgement on the Transcaucasian phenomena and always leaves something new and more correct to be said by the next decade. The relations with immediate neighbours in Transcaucasia are the toughest issues today. In what way is the present day situation different from what happened in the past?

The present paper is devoted to the study of three works written by J.Bryce - a British statesman, jurist and author, H.F.B. Lynch - a British traveller, businessman, jurist and politician, W.Watson - a poet.

The essential thing the books have in common is the fundamental honesty of the authors who see themselves obliged to tell their readers the truth "without a prejudice in favour of either of the states... in the regions... described.”(J. Bryce) The authors do not claim their judgements as final and "absolute truth" and are prepared to leave the assessment of their works to the future generations.

A shrewd foreign observer may reveal significant facets in the life of a country. Thus, it is not surprising at all that J. Bryce, the founder of the Anglo-Armenian Society, in his "Transcaucasia and Ararat" (first edition 1877) gives a popular account of his journey in the autumn of 1876 through the West-Asiatic parts of Russia and Turkey, of his ascent of Mount Ararat on September 12, 1876. Even "the beaten tracks" to which the author almost entirely kept were unlikely to be familiar to English readers. He also complied with curiosity regarding Mount Ararat in England.

Bryce proved to be a capable observer, his chief interest being aroused by ethnological questions, ethnic rivalry and ethnic co-operativenes in the region. His particular interest lies also in the various learned institutions existing in Transcaucasia, with special reference to native literature, literary magazines. The devoted admirer of I. S. Turgenev, whom he presented in the Oxford Sheldonian theatre when the latter received his Doctor of Civil Law, Bryce distinguishes himself in "Transcaucasia and 
Ararat” as a remarkable author. The portrayal of the pastoral beauty of Georgia, the poetic panorama of Armenia with its ancient monasteries, towns and villages, the mountain of the Ark is marked with more than an ordinary narrative skill. Bryce has an important gift of distinguishing the important from the trivial. A considerable part of the book is devoted to the historical and political surveys in the Armenian question.

Bryce disproves the stereotyped conceptions of the Caucasus "as a chain of snowy mountains... inhabited by a race of patriotic heroes and beautiful women.” ${ }^{{ }_{1}}$ Another stereotype he refutes is about "the utterly remorseless Cossacks." 2 The author presents a truthful picture of ethnic rivalry in the Caucasus where almost "each man, like the Cyclopes in Homer, rules over his wife and children, and cares nothing for his neighbours.” Bryce tells his readers about “ne'er-do-wells” of the Caucasian family and "mostly industrious, well-disposed people" of the region. ${ }^{3}$

The phenomenon of brilliant ethnic co-operation the author finds in the capital of Transcaucasia, the city of Tiflis, "a little Paris in its way." "There, without losing their identity, "six nations dwell together in a town smaller than Brighton, and six languages are constantly, three of four more occasionally, to be heard in the streets."

"Probably nowhere in the world," the author concludes, "can so great a variety of stocks, languages and religions be found huddled together in so narrow an area as in the Caucasian chain.”6

The outbreak of Russian-Turkish war (1877-1878) attached unexpected importance to Bryce's book. The competition for influence in Transcaucasia has always been a pressing question. It is obvious that every war brings about certain processes. The Treaty of San Stefano (1878) and the Congress and Treaty of Berlin (1878) redistributed territories, tried to create a new balance of power in the Caucasian subsystem and establish a consensus on common interests.

H.F.B. Lynch's “Armenia. Travels and Studies” written more than twenty years after Bryce’s book showed that common problems still existed for Armenians in the Russian and Turkish empires, however, equitable solutions were never found.

Lynch began his travels in Western Asia (1889) in support of financial interests of Lynch Brothers firm. The journey to Armenia in 1893 was the beginning of his life-long interest in the biblical country. He also made the ascent of Mount Ararat. In 1898 he returned to Armenia and brought out the results of his journeys in a resplendently illustrated 2-volume study which is often considered to be the best travel book about Armenia written in English. Since then Lynch has been recognized an authority on Armenia. Early in the 20th century he received acclaim, though he was reproached for being pro-Armenian. It was obvious that the book should be studied by every scholar and politician who wished to understand the complex ethnic relations in the district. The impact of Lynch's book on the succeeding investigations of the region was great.

A very interesting personality, Lynch was a good writer as well. He had a sense of history and the subtlety of a genuine artist. He captured the imagination of English readers because his vivid pictures of Armenian daily life had both pathos and warmth.

The description of the outskirts of Yerevan produce an almost painterly effect by his juxtaposition of the rich colours of the luxuriant gardens and orchards. ${ }^{7}$ Enthusiastic, 
kind-hearted and slightly humorous is the description of a wedding at Alexandropol. ${ }^{8}$ The author feels genuine affection for and tremendous respect towards Armenian artisans and craftsmen at Van. ${ }^{9}$ The pictures of Dukhobortsy village Gorelovka are invested with dramatic narration. ${ }^{10}$ "The Olympian eminence of the Grand Duke's circle...the steps of the Imperial throne "11 are close to the pictures of a military camp and "abyss of a ... prison". The final paragraph of the chapter "The heart of Ararat" is monumental, solemn and poetical. ${ }^{12}$

Lynch's comments on the religious and political differences in the region, the relations between the Russians, Armenians, Turks and Kurds, the Christians and Muslims, are still cogent. He thoroughly examines the educational policy in the Russian and Turkish provinces of Armenia. "The pillar of Armenian nationality" for long ages has been the Church, "and the schools were affiliated to it". "Perhaps the best introduction to the population of a city", the author believes, "consists in a visit to the schools" ${ }^{13}$ In spite of certain drawbacks, the author could not but "congratulate the State schools" in Yerevan "upon such a salutary feature" as the ability of classmates, "Mohammedan and Christian, Russian Orthodox and Gregorian Armenian," to respect each other and "tolerate each other's faith."14

Each volume has a chapter specially devoted to statistics and politics. Lynch comes to a distressing conclusion on unworthy methods of government in Russia and Turkey, or in "policy adopted by those states towards their Armenian subjects."

For Armenians the 19th century ended with the horror of genocide and extermination carried out in Ottoman Turkey. The massacre of 1895 was not only the tragedy of the Armenian people, "it had touched the conscience of the West," (Lynch) though it remained unpunished. Among those who went heart and soul into defence of dying and homeless people was the poet W. Watson. The tragic voice of the poet sounds in "The Purple East: A Series of Sonnets on England's Desertion of Armenia”. This was a cry of despair and anger against "the continued torture, rape and massacre of a Christian people under the eyes of a Christian continent". ${ }^{15}$ After the publication of the first seven sonnets, there appeared an exasperated reply from A.Austin, the poet-laureate. Austin, known for his affected official verse, had become once more a critical butt. Watson in his answer to the poet-laureate claims that regardless of by whom and against whom it is committed, any crime of genocide should be condemned, "that something besides lamentation alone is even yet possible." "16

Watson hurls bitter accusations upon Turkish murderers, upon all those who had condoned the disgraceful crime. Motifs of denunciation ring through his verses with unusual force. The typical romantic theme of man's defiant faith in struggle against tyranny dominates most of his poems in the collection. Poems such as "The Turk in Armenia”, “Craven England”, “How Long?”, “Repudiated Responsibility”, “The Bardin-Waiting”, "The Plague of Apathy”, pitilessly strip off the dressings from the "passive connivance of non-intervention”. The lyrical note sounds now "with wrath divine," now "cries aloud, with the tongues of thrice a hundred thousand martyrs." The laments in the collection have something in common with some of Byron's verses. Though Watson lacks Byron's celebrated drive and vigour, the emotional climate of "The Purple East" may be compared with that of "Journal in Cephalonia". Both the poets treated art as a 
vehicle of social conscience, both may be referred to as "the poets of world sorrow." Like his famous precursor, Watson exclaims, "Because I crouch not fawning slaves among, how is my service proved the less sincere?" 17

The eternal questions Watson puts in his sonnets contain more than condemnation of genocide. The poet raises the questions of liberty and violence, of great responsibility of man and of state towards history.

But if ye could and would not, oh, what

plea,

Think ye, shall stead you at your trial,

when

The thunder-cloud of witnesses shall loom, With Ravished Childhood on the seat of doom, At the Assizes of Eternity? ${ }^{18}$

The "cruel age" of Transcaucasia is not yet over and Watson's sonnets still, years later, touch the right chord in modern readers.

The keen observations of J. Bryce, H.F.B. Lynch, W. Watson on national and regional identities, on the competition for influence in Transcaucasia, on the language policy in the region are pressing questions today when a new world order is in the works.

\section{References:}

1. Bryce J. Transcaucasia and Ararat, London: Macmillan, 1896, p.43

2. Ibid., p.307

3. Ibid., p.62

4. Ibid., p.121

5. Ibid., p.119

6. Ibid., p.120

7. Lynch H.F.B. Armenia. Travels and Studies. 2vols, Longmans, 1901, v.1., p.142

8. Vol.1, p.129-131

9. Vol.2, p.90-91

10. Vol.1, p.115, 116

11. Vol.1, p.54, 55, 58

12. Vol.1, p.196-197

13. Vol.1, p.218

14. Vol.1, p.224

15. Watson W. The Purple East: A Series of Sonnets on England's Desertion of Armenia. Preface, p.8

16. Ibid; p.9

17. Op. cit., p.17

18. Op. cit., p.42 


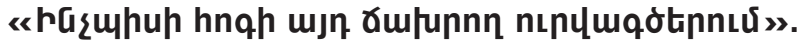

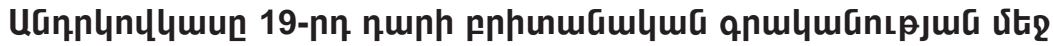

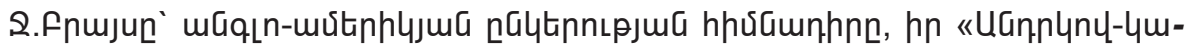

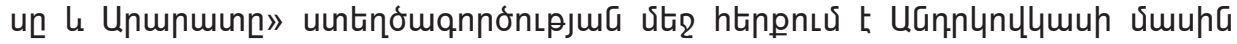

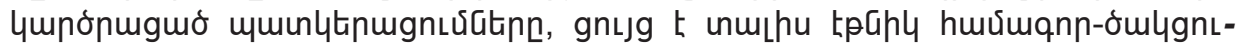

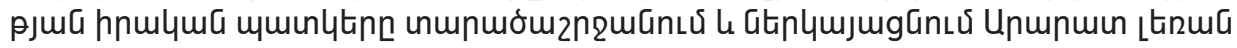

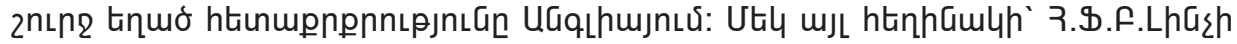

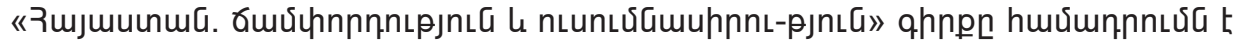

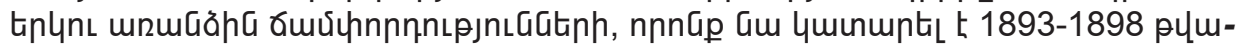

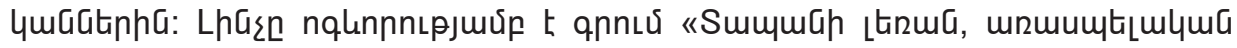

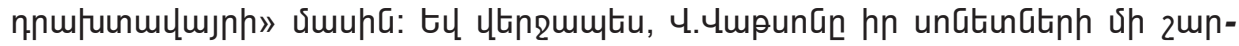

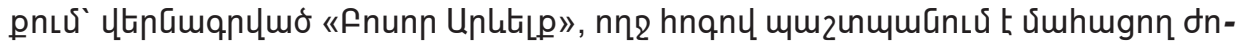

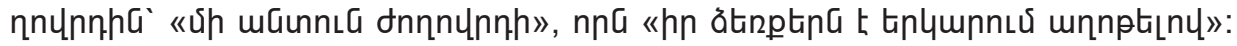

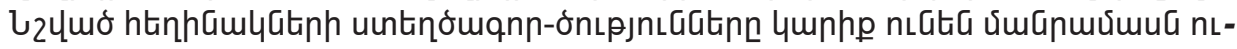

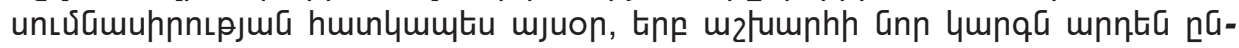
pugp t untl: 